\title{
Ethical care of the other: Edith Stein and Max Scheler's contributions
}

\author{
Cuidado ético do outro: contribuiçōes de Edith Stein e Max Scheler \\ Cuidado etico del otro: contribuciones de Edith Stein y Max Scheler
}

Valdecyr Herdy Alves ${ }^{1}$ Rudimar Barea ${ }^{2}$ Vera Rudge Werneck ${ }^{3}$ Silvestre Grzibowski Diego Pereira Rodrigues ${ }^{1}$ Luana Asturiano da Silva ${ }^{1}$

1. Universidade Federal Fluminense.

Niterói, RJ, Brasil.

2. Universidade Federal de Santa Maria.

Santa Maria, RS, Brasil.

3. Universidade Católica de Petrópolis.

Petrópolis, RJ, Brasil.
Corresponding author:

Diego Pereira Rodrigues.

E-mail: diego.pereira.rodrigues@gmail.com

Submitted on $12 / 03 / 2017$

Accepted on 04/06/2018.

DOI: 10.1590/2177-9465-EAN-2017-0382

\begin{abstract}
Objective: To analyze the empathy of Edith Stein and the sympathy of Max Scheler for an ethical care of the other. Method: A reflexive, philosophical study anchored in the philosopher Edith Stein's thoughts about empathy for the care of the human person, and likewise of the philosopher Max Scheler on sympathy. It intends to converge the thoughts of the thinkers with the intention of presenting the importance of the care with the person. Results: Stein's empathy leads the human being to perceive the experiences of others and the need for the ethical care of the other; Scheler, in relation to sympathy, brings love as the basis for the ethical care, essential in this relationship with the other. Conclusion: Life and care are become necessary for human relationships, and thus, according to Stein and Scheler's philosophies, each person is invited to perceive the other as a human being.
\end{abstract}

Keywords: Ethics; Empathy; Standard of care; Patient-centered care; Qualitative research.

\section{Resumo}

Objetivo: Analisar a empatia de Edith Stein e a simpatia de Max Scheler para um cuidado ético do outro. Método: Estudo reflexivo, filosófico ancorado nos pensamentos da filósofa Edith Stein, com relação à empatia para o cuidado da pessoa humana, e do mesmo modo, do filósofo Max Scheler acerca da simpatia. Pretende convergir os pensamentos dos pensadores com o intuito de apresentar a importância do cuidado com a pessoa. Resultados: A empatia de Stein leva o ser humano a perceber as vivências alheias e a necessidade do cuidado ético do outro; Scheler, em relação à simpatia, traz o amor como base para o cuidado ético, essencial nessa relação com o outro. Conclusão: A vida e o cuidado tornam-se necessários para as relações humanas e assim, de acordo com as filosofias de Stein e Scheler, cada pessoa é convidada a perceber o outro como ser humano.

Palavras-chave: Ética; Empatia; Padrão de cuidado; Assistência centrada no paciente; Pesquisa qualitativa.

\section{Resumen}

Objetivo: Analizar la empatía de Edith Stein y la simpatía de Max Scheler para una ética de la atención del otro. Método: Estudio reflexivo, filosófico anclado en los pensamientos de la filósofa Edith Stein, con relación a la empatía para el cuidado de la persona humana, y del mismo modo, del filósofo Max Scheler acerca de la simpatía. Pretende converger los pensamientos de los pensadores con el propósito de presentar la importancia del cuidado con la persona. Resultados: La empatía de Stein lleva al ser humano a percibir las vivencias ajenas y la necesidad de la ética de la atención del otro; Scheler, en relación a la simpatía, trae el amor como base para la ética de la atención, esencial en esa relación con el otro. Conclusión: La vida y el cuidado se hacen necesarios para las relaciones humanas y así, de acuerdo con las filosofías de Stein y Scheler, cada persona es invitada a percibir al otro como ser humano.

Palabras clave: Ética; Empatía; Nivel de atención; Atención dirigida al paciente; Investigación cualitativa. 


\section{INTRODUCTION}

Ethical and empathic care is essential on the development of human relations and interactions, which transforms the health space into one of the environments that need a lot of attention because it's the one where the human needs humanized care, being the assessment one of the pillars of care. ${ }^{1}$ Based on human values and aiming to ensure well being of health services' users, the care offered to the other must be comprehended in the perspective of the human person, involving biological, psychological, social and cultural. ${ }^{2}$ In this study, aspects of care of the human person guided by empathy, Edith Stein way, or sympathy, e Scheler way, are problematized.

We are based on the Edith Stein's thinking in the field of empathy and ethics, themes presented in the perspective of the care of the other. Empathy is defined as an affective response of the other, starting from the apprehension and the understanding of his feelings and of how he apprehends a certain situation. ${ }^{3}$

Relating to sympathy, there are Max Scheler's reflections as phylosophical contributions, he is the author of Value Theory, ${ }^{4,5}$ according to whom coexistance enables human beings not only to recognize themselves through empathy, but also, showing the possibility of affective participation denominated sympathy, which is the affective unification that motivates caring for another. ${ }^{6}$ In that sense, the phylospher present a vision of the human being in three levels of evolution: 1 ) in the lowest, we find those who dedicate themselves in sensory values (pleasure and pain); 2) in the middle, those who prefer affective values linked to emotions, considered vital because they compose psyche order; and 3) in the spiritual leval, the highest, those who preserve values that are spiritual or sacred. ${ }^{4}$

Thus, the study aimed to analyze the empathy of Edith Stein and the sympathy of Max Scheler for an ethical care of the other.

\section{METHOD}

Bibliographical, reflexive and phylosophical study, anchored in the thoughts from the phylosopher Edith Stein, related to empathy, and the same for the phylosopher Max Scheler, about sympathy. We aimed to converge their ideas in order to present the importance of ethical care for the other, as both thinkers aimed the relationship with human care.

\section{RESULTS AND DISCUSSION}

\section{Edith Stein's empathy in caring for a human person}

Edith Stein left as legacy a great phylosophical contribution that is due to the intense dedication in everything that did, to have extreme personal commitment, delicacy with the knowledge and care with the integrity of the human person, thinking about the human situation and helping to take care of many where it happened.

When we talk about ethical care, we are directed to a field known as stabilished relationships in our lives with other people. To develop this care, human go through a learning process of love and care, eanbling human capacity of empathize. ${ }^{7}$ Stein contributes with the care problematization with the other, characterizing this possibility through empathy (originally from German Einfühlung).

Phylosophical research is based on giving consistency in the plurality of subjects in the intersubjective relationship. She developed her thesis bringing her theory, specially with thoughts from Theodor Lipps and Max Scheler, deepening the possibility of reaching the knowledge of the experience of others and understand it from their corporeity.

Stein's project, essentially in her main (About the theme of empathy), is given around the specific meaning of empathy "as the knowledge act sui generis". 8:36 "Seeking to enlight the true essence of empathy", 8:36 with rigorous phenomenological matrix, she started with the following exemple: "a friend comes to me and tells me he lost his brother and perceive his pain. What is this perceive? [...] what that perceive is in itself, and not through which pathways to be possible to get to it. This perceive is important to get to the essence of the empathic moment".9:74

According to the phylosopher, the access to the moment of perception of the other's experience devide three degrees of the act of empathy:

1) the emersion of the lived experience; 2) it's whole explanation; 3) the comprehensive objectification of lived explained. Characterization of these degrees to get to the knowledge of the other's conscience of the full empathic moment, it would be in the following way: in the first and thrid degrees, the act of realizing the other's lived experience corresponds to the non original way in the perception; also this would not originates the other's pain, seen as an object, while the second degree the same act corresponds to the empathic experience getting to the conclusion: live the lived experiences of others as if it was my own. It is, thus, the second degree of empathy that reaches fullness. ${ }^{9: 73}$

To capture the lived experience of the other in it's essence (not as original way) is a possibility to the empathic act. This "realizing the other's lived experience, implies in always being accompanied with the other's lived experience as it was our own". 9:74 This is the essence of the empathic process, as explained by Edith Stein:

In my non-original lived experience, I feel accompanied by an original lived experience, which wasn't lived by me, but it announces itself to me, manifesting itself in my non-original lived experience. In which way we arrive through empathy of a to a kind of sui generis experiential acts. ${ }^{10: 79}$ (our griffin)

In this way, who empathically intends to perceive the other, must be attentive to the experiences of others who present themselves, in whose significance it is possible to perceive the 
experience of the other. From them on, it is possible to speak of "ethical care" in view of the other's well-being, just as we want it for ourselves. We consider, however, that the 'self' while subject of action, and the 'other', while subject of the lived experience.

With effect, the empathic perception of the other "is not only with the physical body (Körper), but also for the own body (Leib) endowed with sensitivity", 9:47 "a 'Self' capable of having the sensation, of thinking, of feeling and wanting. Thus, a body is not only part of my phenomenal world", $9: 51$ but that is it's own center of orientation of a similar phenomenal world. Thus, the empathic moment enables to know correlation of other lived experiences, being joy, sadness, in it's phenomenological space and time, in which I am invited to realize, to know about the concrete situation that emerges in my being.

This realizing, for Stain, goes through empathy in the moment in which the other's lived experience is highlighted in another since it's singularity. The subject of empathy, "in this case, it doesn't belong to the being 'Self', but the other of the relationship, one who vividly demonstrates the originality of his/her act", $9: 74$ as the exemple by Edith Stein: ${ }^{11}$ "while I live joy that is experienced by the other, I don't perceive an original joy: it doesn't rise ${ }^{19: 74}$ from the lived experience of:

My 'Self', nor does it have the character of having previously been alive as a remembered joy, much less as merely fantasized, that is, deprived of real life, but is precisely of the other, of the one who experiences in a lively manner such origin; the joy that comes from it is original, although I do not live it as a whole. ${ }^{8: 43}$

The lived experience of empathy ${ }^{9}$ is not originated by Stein, since the content of the empathetic presentiment is the experience of the other, not mine. With effect, it causes us to highlight the characteristics of this experiential act that belongs to the other. ${ }^{9,12}$

Empathy enables to comprehend the singularity of the lived experience of the other. "If I see looking at the world with his look, now I attribute you a perception of this world, that is the same I realize of it's way; but if substitute my way of seeing it, behave to one's place", 9:79 appears in appearance different from my own current perception.

Lived experiences are always singular and particular; and for being that way, "they teach a new way of putting yourself into the world, beyond a new way of seeing them and, this is only possible because we have a general structure similiar to our lived experiences". 9:80

As presented by Stein, empathy shows the possibility of each one to exercise the capacity of realizing the need of the other (that can be physical, psychic or even a spiritual motivation) and to act coherently to the well being of the human life, caring ethically for the other.

We speak of ethical care on identifying human relations, problems for it's own effectiveness. Thus:

\begin{abstract}
All action from the subject, inevitably and without exception, is a concrete manner of fulfilling a production, reproduction and developing requirement of the human life, from which the foundation can develop ethical orders, that open themselves as concrete alternatives of development of life. ${ }^{13: 144}$
\end{abstract}

To consider alterity reinforces human's life dignity and rights, that can only be known by the own human beings when they are aware of the situation, being calamitous or full of happiness.

\section{Max Scheler and sympathy in the caring for others}

The sympathize conduct of individuals, according to Scheler, it derives from the ethical care to the other. Sympathize the lived experience of the other goes beyond valuing feelings of hate, joy or sadness of the other. Sympathize to other lived experience unveils itself as an act of love to the other. To act according a sympathized conduct is an inherent act of human beings that meet each other. However, the effectiveness of the sympathization act in Scheler ${ }^{14}$ is full when accompanied by love, that aims in caring for the other, as love is particular form of the sympathizing condition.

Love drives itself fully to the values of the person itself, without the need of a mixture with own values or with preexisting excluding norm, that proposes new ethics that has caring as the center of the human life, as it may be seen in Scheler: ${ }^{15}$ all norm is based on values, but, at the same time, formal more elevated value is a real value (of something), not even a value of situation, but before a person's value. For Scheler, the person is the center of all the ethical fundamentation, and genuine acts of sympathizing sports a positive ethical value. Sympathy, according to Scheler, is found intrinsically linked to aspects of caring for a human person.

According to Scheler, it is important that human beings can comprehend themselves without mixing their feelings. For exemple: to comprehend joy, without becoming happy, recognizing the joy of the other keeps a certain distance from ones feelings. ${ }^{14}$ Thus interpreted, sympathy takes to the transcendence of the own's self, liberating the egocentrism of which it's possible to sympathize even with the one we don't love. However, the act of sympathize has to be immerse in an act of love that embrace it, and therefore, gets to be more than a comprehension and feeling the same as the other. Just because this addition is warm, it is very possible to sympathize with someone we don't love, but is excluded the not sympathize there where we love. The act of love is what determinates radically, with it's own sphere radius, in which the way is possible to have sympathy. ${ }^{14}$

Scheler indicates that in the sympathize process, the individual can perceive the other's lived experience, and and yet do not sympathize with their experiential state. For the philosopher, it makes perfect sense to say: I feel very well the same as you, but I have no compasion for you. ${ }^{15}$ The individual can be only in the cognitive comprehension sphere and not to act, 
however, in the act of sympathizing with the other's experience, all are impulsionated to react and not to seem indifferent. If the other falls in front of us, we are provoked by the lived experience of sympathizing to give him a hand, instead of perceiving and turn our backs.

Sympathy is a phenomenon in the face of the perception of an untimely state of mind to which we react positively (congratulation) or negatively (compassion). For Scheler, this other perceived state will not be in any way an object, because the man in it's totality doesn't realize the other only with the material object, but as an spiritual being.

It is possible to transcend the process of knowing and recognizing the subject (the other) beyond the cognitive perception, realizing it while spiritual being, a being with value in itself, experiencing something with the other from one's alterity. The philosopher ${ }^{14}$ says still this process is of recognizing/ knowledge with the other. Experiencing together is what he denominates sympathy. Sympathy manifests iself in the emotive life, from which it is possible to comprehend that the other live. It is a step beyond comprehension, feeling with, because it refers the sympathing subject to the puer experience of the other in his/her integrity, with love for the person. ${ }^{16}$

It's in this sense that love is fundamented, because it seeks and uncover values that, in another way, remain hidden. Love is a puer sentiment, it enables being among people/subjects and it gives opportunity of a meeting without pre-conceptions or pre-judgements. For exemple: a person who is willing to help a community with food donations denotes an attitude that is different from the one that is effectively available to help people who lack food, after having known the precarious situation in which they find themselves. In the initial situation, there is only the emotional state, resulting from the vital perception of fact; in the second situation, there is a feeling that leads the subject to develop an action.

Max Scheler proposes "as knowledge process, the phenomenological experience that occurs in subjet's direct contact with reality", $5: 6$ this because there is no need of anotehr interferance, because some things are aprehended in themselves, without needing new meditation Reality in the phenomenological approach is constituted by experiences from the object aprehended by intention. However, it is noted in the phenomenological sense, experiences don't confuse themselves with experiences purely psychological.

Scheler clarifies that the aspect of sympathy and love fits: sympathy fits in the field of stimulation reactions of "sensitive nature, a tendency that is satisfied in itself and quiets itself with ownership from it's object" . ${ }^{5: 6}$ As for love, it doesn't reduce itself in a mere affective fleeting and passenger state; on the contrary, for being essentially dynamic and spontaneous, it tends for another with that holds an unique value, exclusively; this, it's stable and permanent.

Scheler ${ }^{14}$ afirms that love is an spontaneous act and in it, it's included the "reciprocal love", if you would like it to be founded.
The same way, all sympathizing is founded in love, and without love, it ends. Love and sympath are people's lived experience and result from the perception of the other. We aprehend the other, first, it's expression, that is a maniestation of the pstchic state while inherent from the physical one. We perceive another by it's meaning expression, being gestural or oral. We aprehend, first, not one's body (Körper), nor it's individuality, but all it's undevided intuitevily.

We are considered a "self" thus perceived as representing a particular individuality, not by the fact that we know it perceiving another body, but because the "self", as we learn, independently of it's relations with the other any body, represents for us a different "individual" of our "self". This is the only reason which we considered as the "other" for the individual, and not individual for the "other". 16:354

In the philosopher's understanding, the perception of other is of an immediate way. The perception of other doesn't mean any participation in his/her personal existence, that happens through sympathy and love, that enables the overtaking of an egocentric posture and the access to the essence of the other without loss of one's own identity. Sympathy conducts comprehension to the other way of enabling communication with one's live. It's an intentional posture that takes one to recognizing the situation of the other, of one's point of view and ways of living.

On treating the issue of sympathy, Scheler comes from a phenomenological approach of "intentionality" and of the category "person" as center of intentional acts, since the care of the other is to perceive it in its fullness and completeness, enabling it to receive sympathetic care, understanding the various values present in the being that is cared for.

\section{Empathy and sympathy: fundamental teams for ethical care in human life}

Based on what was ellaborated above, we perceive that both Stein's empathy and Scheler's sympathy are intimately linked to our human acting Cas an act of perception of lived experience of others, in both philosophical theories (that are also nuances from psychology) taking the sympathizing or empathizing human to caring for the other with love.

Aspects of ethics and care with the human person are essential elements of living well. From themes by Edith Stein and by Max Scheler, we perceive the contributions by both philosophers for the human relations to be zealous. We believe that empathy, as Wella s sympathy, are meaningful and can contribute to improve human relationships.

In reference to ethical care to the human live, we resort to Stein for understanding she was always concerned with the human person's integrity, that it should be considered in it's fullness, before any vestige of preconception that we can express. In sympathy, the other's originary lived experience 
manifests before us, refers to a reflective effort aout the lived experience. Presentification of this lived experience enables approaches to the other's lived experience through effectiveness, demanding from the empathic subject a conversation of looking by it's own humanity. ${ }^{11}$

On the other hand, Stein show us "that the act of empathy is concrete, it happens here and now"8:35 in flesh and bone, leading us to an opening in alterity, since the human individual exists in the world, here and now; so your life is life in common. Empathy is a movement of phenomenological evidence of the other's empathic lived experience. "Actually, phenomenologically there is the encounter, empathy as lived experience that always happens and", 17:15 will happen, being possible to facilitate the "empathy conscience as present element in the intersubject relationship". ${ }^{17: 15}$

"Therefore, even with the fundamental contributions of the explanation of the presence of empathy in the area of Health, stimulating attention"17:15 that should be highlitened "the importance of this concept, of mistakes associated to empathic lived experience being a instrumental concept, empty the very ethical scene originated from this experience and guaranteed by the re-actualization of the phenomenological orientation to the world of life". ${ }^{17: 15}$

In a hypothetical situation, when we assume that the other's experience belongs to the set of experiences that shapes our own life, we are conditioned to take responsibility from the ther as someone similar to us, because I don't live only my life, but I am also responsible for the live of the other that emerges in front of me and reaches my existance.

Empathy provides the possibility to act ethically, to care for human life that is wounded, while at the same time perceiving the intensity of people's feelings as joyful or sad, healthy or sick. Faced with such a perception, subjects can analyze all the favorable and contrary reasons of their actions in view of a greater good, that is humanity: to act in a responsible and careful way, or to be indifferent to what happens. I could be said that empathy enables thinking ethics, even if I don't live injustices that others suffer, because I can comprehend how dignity and intrity are wounded by human beings.

If we put the person and one's integrity in the center o four attitudes, we may recognize ourself each time more and discover our new forms of understanding human beings, bearers of capacities to aspire to the common good, since we are similar and we live in the same world, in the same historical period. From the moment we consider the other while other, we realize that what unite us and that has fundamental value is life.

"The fact of life is a fundamental value in relation to it's value. And, this way, with new obtained value through empathy, the look unfolds simultaneously on the unknown values of the person himself". 8:42 It's from the intersubjective experiences with the other that the individual comprehends oneself, is aware of one's true invididuality and freedom to act ethically in the collective life. When we meet in the intersubjetive relationship, we can not think of problems of another order, unless of putting oneself in position of mutual understanding, of respect, of of recognition and hospitality.

On the other hand, Scheler inferes that the act of sympathizing or sharring affective perceptions is a transcendental possibility of the human emotive world, that guarantees objectiveness of sympathy in the field of caring with the other in it's alterity. The author reinforces that sympathy is consituted ofthe a priori element of the subject while person, because the other's world, one's experience and ours, are in the ontological field.

Sympathize with the other is, thus, an stabilished impulse by emotive reactions inherent to each human being. In this sense, both subject enable ethical care communication, that necessarily is feeling the other's pain or allergy, even without experiencing it originally. Sympathy, for Scheler, ${ }^{14}$ is in the motive life field, in feeling, it originates in the subject that sympathizes with the other, in the intersubjective field, that comprehend intrapersonal worlds that communicate themselves in the world: Self and You related to sympathized care, as you can infere in one's words: what always works in this process as essential complex, reduces to these propositions: 1) Every lived experience belongs to a general self, and when there is lived experience, there is always a general self with it; 2) This 'self' is by necessity essential, an individual self that is present in every lived experience, however, it happens properly; that, thus, it is not constituted by a set of lived experiences; 3 ) there is a general self and you; however, that the individual self is the one that belongs to the "lived" lived experience if our own or another's, is not necessarily given with the primary giving of experiences.

Since our own singularity, the other presents iself in an intersubjective relationship with us. This other is worthy of singular lived experience that demands our respect, care and love, when observed issues that are realted to preserving dignity and ethical responsible care for one's life.

\section{CONCLUSION}

Empathy and sympathy may help understand the weeds of our society, that still live in barbarism state in the middle of this kind of race against time for the improvement of the technique, preventing the population from finding a 'time' to listen to their daily affections.

Stein and Scheler taught the importance of living respecting and valuing the other with his/her values, his/her feelings and his/ her acting in the community one lives. Therefore, and face what was exposed, these two philosopher's teachings are relevant so we can deepen more each time our intersubjective relationships, being empathically or through sympathy, in love or ethical care with the other.

Care for the other has a peculiar field for care before philosophical thoughts from Steins' empathy and Scheler's sympathy, identifying that are applied to promote integral practive through a relationship that express an integral care, before needs of the other as a human person, which legitimize the practice for their care, thereby justifying professional action. 
Caring for the other is a peculiar field before philosophical thoughts from Stein's empathy and Scheler's sympathy. The first one brings the other in it's essence, in a non originary way, as a field for the empathic act; while the second speaks from the comprehension and understanding of lived experiences, since the individual can perceive the experience of the other.

To unveil fields of empathy and sympathy favours reflection on caring for the human person, sharing one's feelings, being able to experience this care, using the empathy to feel what the other feels and thinks, making the relationship affective and sympathetic, thus contributing to the ethical and essentially human health care, indispensable to its health professionals, especially those who work in the area of Nursing.

\section{REFERENCES}

1. Pessini L. Life and death in the ICU: ethics on the razor's edge. Rev Bioét [Internet]. 2016 Jan/Apr; [cited 2017 Nov 12]; 24(1):54-63. Available from: $\mathrm{http}: / / \mathrm{dx}$.doi.org/10.1590/1983-80422016241106. DOI: 10.1590/1983-80422016241106

2. Olivé CF. Cuidado humanístico y transpersonal: esencia de la enfermeria en el siglo XXI. Fundamentos disciplinares. Salus [Internet]. 2015; [cited 2017 Nov 12]; 19(3):20-6. Available from: http://www.scielo. org.ve/pdf/s/v19n3/art05.pdf

3. Mayernyik MA, Oliveira FAG. O cuidado empático: contribuições para a ética e sua interface com a educação moral na formação em saúde. Rev Bras Educ Med [Internet]. 2016; [cited 2017 Nov 12]; 40(1):1120. Available from: http://www.scielo.br/pdf/rbem/v40n1/1981-5271rbem-40-1-0011.pdf. DOI: 10.1590/1981-52712015v40n1e01752015

4. Scheler M. Da reviravolta dos valores. $2^{\mathrm{a}}$ ed. Petrópolis: Vozes; 2012. $182 \mathrm{p}$.
5. Alves VH, Padoin SMM, Rodrigues DP, Silva LA, Branco MBLR, Marchiori GRS. Clinical management of breastfeeding: axiological value from women's perspective. Esc Anna Nery [Internet]. 2016; [cited 2017 Nov 12];20(4):e20160100. Available from: http://www.scielo.br/pdt/ean/ v20n4/en_1414-8145-ean-20-04-20160100.pdf. DOI: 10.5935/14148145.20160100

6. Cadena NB. Scheler, os valores, o sentimento e a simpatia. Rev Ética Filos Polit [Internet]. 2013; [cited 2017 Nov 12]; 16(2):76-88. Available from: http://www.ufjf.br/eticaefilosofia/files/2009/08/16_2_cadena.pdf

7. Stein E. A mulher: Sua missão segundo a natureza e a graça. Trad. Alfred J. Keller: Bauru (SP): EDUSC; 1999. 304 p.

8. Grzibowski S, Barea R. Empatia e ética na fenomenologia de Edith Stein. Ágora Filosófica [Internet]. 2015 Jul/Dec; [cited 2017 nov 12]; 1(2):34-46. Available from: http://www.unicap.br/ojs/index.php/agora/ article/view/714/567

9. Rudimar B. O tema da empatia de Edith Stein [dissertação]. Santa Maria (RS): Universidade Federal de Santa Maria, Programa de Pósgraduaçãoem Filosofia; 2015. $117 \mathrm{p}$.

10. Costantini E, Costantini ES. Notiziebibliografiche e Introduzioni. In: Stein E, ed. II problema dell'Empatia. Roma: Edizioni Studium; 2003. p. 12-59.

11. Stein E. Il problema dell'Empatia. Roma: Edizioni Studium;2003.271p

12. Stein E. Introduzione alla Filosofia. Roma: Città Nuova; 2001. 208 p.

13. Dussel E. Ética da libertação na idade da globalização e da exclusão. $3^{a}$ ed. Petrópolis (RJ): Vozes; 2007. 672p.

14. Scheler M. Esencia y formas de la simpatia. Tradução José Gaos. Buenos Aires: Ed. LOSADA. S. A.; 1957. 364 p.

15. Scheler $M$. Le formalisme en éthique et l'éthique material e desvaleurs. Paris: Gallimard; 1955.640 p.

16. Scheler M. Nature et formes de la sympathie. Paris: Payot; $1950.390 p$

17. Ranieri LP, Barreira CRA. A empatia com vivência. Memorandum [Internet]. 2012 Oct; [cited 2017 Nov 12]; 23:12-31. Available from: http://www.fafich.ufmg.br/memorandum/wp-content/uploads/2012/10/ ranieribarreira01.pdf 